\title{
BIBECHANA
}

A Multidisciplinary Journal of Science, Technology and Mathematics

ISSN 2091-0762 (online)

Journal homepage: http://nepjol.info/index.php/BIBECHANA

\section{Some Wild Mushrooms of Rupandehi District, West Nepal}

\author{
H.P. Aryal $^{1^{*}}$, U. Budhathoki ${ }^{2}$ \\ ${ }^{1}$ Bhairahawa Multiple Campus, SiddarthaNagar, Institute of Science and Technology, Tribhuvan \\ University. \\ ${ }^{2}$ Central Department of Botany, Kirtipur, Kathmandu, Tribhuvan University, Nepal \\ *E-mail: hahariprasadaryal06@gmail.com \\ ${ }^{2}$ Email: drushabudathoki@yahoo.com
}

Article history: Received 25 October, 2012; Accepted 1 November, 2013

\section{Abstract}

This mycological investigation carried out at natural as well as community managed forest, of Rupandehi district, western terai and siwaliks region of Nepal. Samples were collected in different area ranging between 90 and 1229 masl in tropical deciduous riverine forest, to subtropical deciduous hill forest. This paper highlights on common wild mushrooms Amanita chepangiana, Geastrum fimbriatum, Macrolepiota procera, Pycnoporus cinnabarinus, Schizophyllum commune, Scleroderma bovista and Sparassis crispa. The collected samples represented seven species of Basidiomycetes belongs to four order and seven families. The specimens were deposited in the Tribhuvan University Central Herbarium, (TUCH), Kathmandu, Nepal.

Keywords: Basidiomycetes, Macrofungi, Mushroom diversity, Taxonomy.

\section{Introduction}

Taxonomy of this genus has been based mainly on basidiocarp, macro morphology, basidiospore size $\&$ host plant type [1]. The species of mushrooms in Nepal is expected to reach more than 3000 due to the large variation in climatic condition and vegetation types [2]. The taxonomic approach has been made here along with distribution.

\section{Study area}

The study area (Map 1) is the southern belt of west Nepal and lies in, Lumbini zone, Rupandehi district. This area is a tropical to subtropical zone embracing different types of soil and forests. The forest vegetation is dominated by members of the Dipterocarpaceae, Combretaceae, Fagaceae and Leguminosae. The study area included 19897 hectares of forested land [3] and Lies between

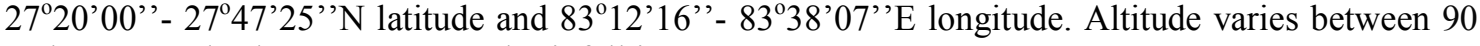
and 1229 masl. The average annual rainfall is $1391 \mathrm{~m} \mathrm{[4].}$

\section{Materials and methods}

Surveys were under taken and specimens collected from $15^{\text {th }}$ to $31^{\text {st }}$ May and from $1^{\text {st }}$ June to $31^{\text {st }}$ October in 2011 and 2012 respectively. Mushroom samples were photographed in their natural habitat 
and their morphological characters were noted. The samples were well dried and packed in wax-paper bags wrapped with aluminium foil to prevent external infection and intermixing of the spores and labeled. The habitats including ecological parameters viz. altitude (by altimeter, Model No. 7030, Japan), vegetation composition, soil type, soil pH (by digital $\mathrm{pH}$ meter, Model No.335, Systronics, Ahmedabad, India, Serial No. 2719), soil moisture (by nail pH meter, Model: Takemura, Japan), humidity, temperatures and time (by means of Thermo-Hygrometer-Clock, Model: TempTec, Hong Kong), with macroscopic and microscopic characters of the specimens were noted. The wax-paper bags were brought to Central Department of Botany, Tribhuvan University, for further microscopic examination.

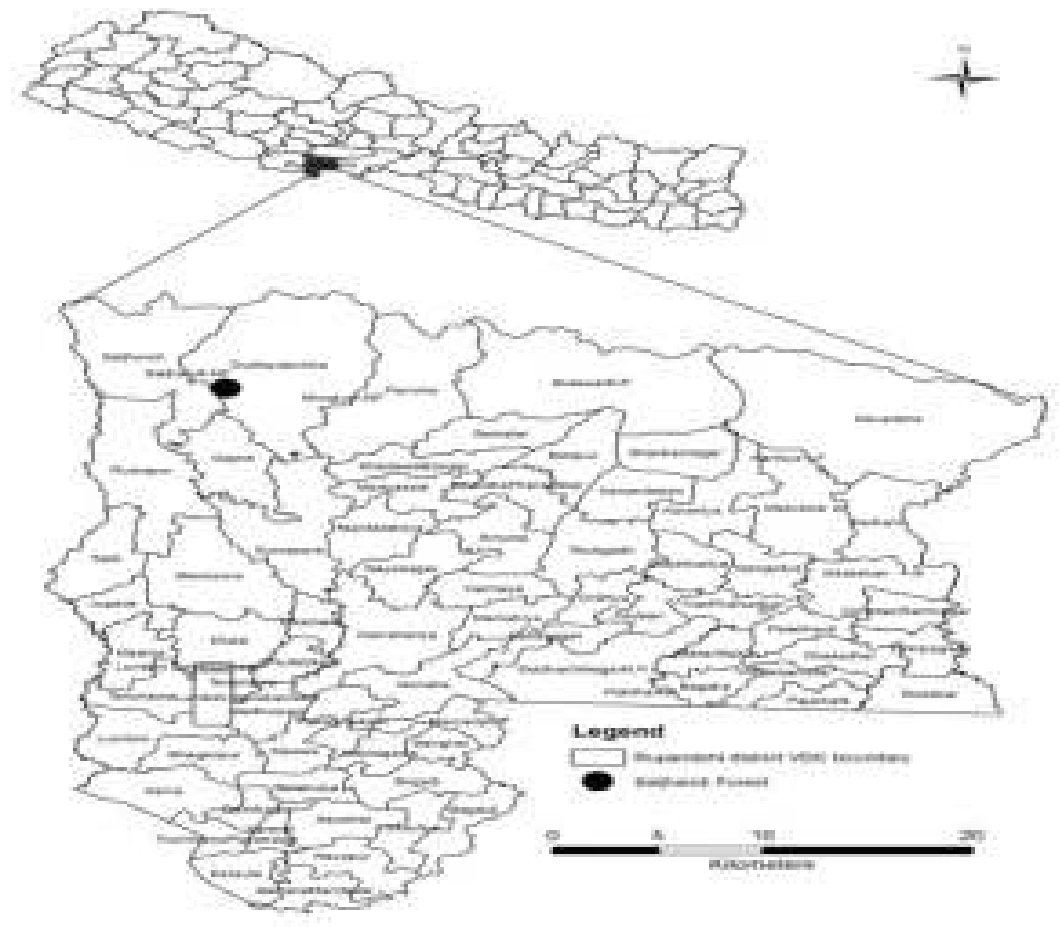

Map 1: Sample Collection site.

A number of the collected specimens were preserved in 25:5:70 $\mathrm{ml}$ rectified alcohol: formalin: distilled water [5]. For microscopic study the specimens were sectioned using a sharp razor blade. The cyanophility was observed by placing the parts of species in cotton blue and mounting in lactophenol reagent. Photographs were taken with a digital camera (Sony DSC S980 camera, China) and macro and micro characters studied under an Olympus microscope (Model No. CX 22). Latitude and longitude were recorded by means of GPS compass (Garmin, Eterex, Germany). The voucher specimens were identified [6-25] and are deposited in Tribhuvan University Central Herbarium, (TUCH), and Kathmandu, Nepal. 


\section{Results and Discussion}

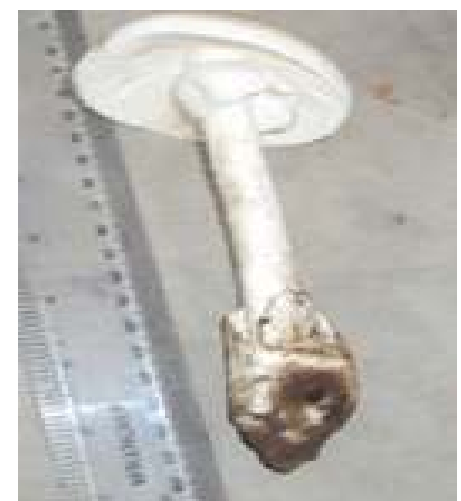

Fig. 1: Amanita chepangiana Tulloss \& Bhandary [26]

Common name: Chepang slender, Caesar (Eng.).

Local name: Gobre musa (Chepang), Salleu (Magar), Vaam waam moo, Naagfum, Seto Kukhura phooey chyau (Nepali.)

Taxonomic position: Basidiomycetes, Agaricales, Plutaceae.

\section{Description:}

Pileus: $13-19 \mathrm{~cm}$ wide, convex at first later umbrella like pure white, sometimes with a slight grayish to brownish or yellowish tint over the center. Gills: Lamellae free, close to sub crowded, white, and truncate. Stipe: $15-18 \mathrm{~cm} \mathrm{X} 2 \mathrm{~cm}$, cylindrical white, annulus skirt like, white found just below the cap, white. Volva: large, membranous, white, saccate. Spore: 9-12 X 8-10 $\mu \mathrm{m}$, white, subglobose, inamyloid. Spore print: white.

Edibility: edible, preferred by Chepang ethnic cast, excellent. Rs. 250 to $300 / \mathrm{Kg} \mathrm{NC}$, in the local market. Distribution: Mostly in Shorea robusta forest. Occurs in Fagaceous forest also-China, South East Asia and Nepal

Habit: Sporophores growing solitary or scattered, sometimes in clusters.

Habitat: On soil, mycorrhizal.

Season: June to August.

Specimen examined: On the litter of the soil, in Shorea robusta dominant forest of Karhiya, 223m, Paklihawa, 90m, Chiliya, 110m, Murgiya, 233m , Saljhandi, 262m, Simalpani,1225m (Rupandehi), (2011); Voucher No. 100772, Aryal, H.P.; New to area of collection.

Previously reported: From Jugedi, Chitwan [2, 26, 27, 28, 29, 30].

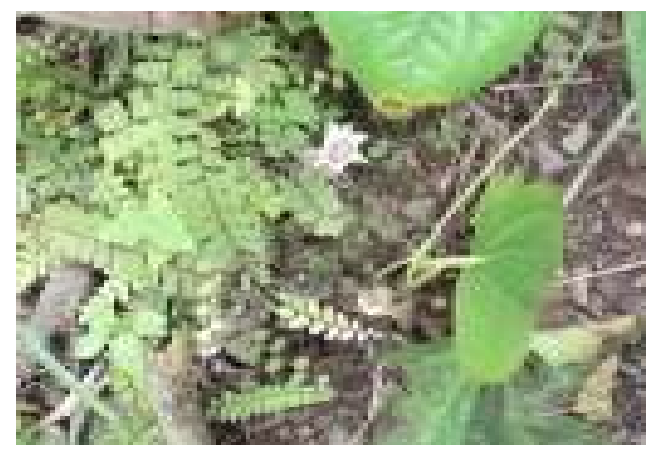

Fig. 2: Geastrum fimbriatum Fr. Butler, E.J. \& Bisby, G.R. [18, 31]. 
Common name: Earthstar, Sessile earthstar, Geastre fimbrie.

Local name: Tare chyau

Taxonomic position: Basidiomycetes, Phallales, Geastraceae.

Description:

Basidiocarp: Close globose, up to $7 \mathrm{~cm}$ in diameter. Exoperidium: opening into 6-9 triangular fringes, turned downward, chamois-colored, thin, membranous, separable, whitish. Endoperidium: globose, sessile, same color as exoperidium, with fairly salient apical opening, edge fibrous. Gleba: powdery when mature, cocoa-brown. Flesh: leathery, Odor: not distinctive, Spores: 3-4 $\mu \mathrm{m}$, cocoabrown, rounds, finely warty.

Edibility: Inedible.

Distribution: Europe, Japan, North America and Nepal.

Habit: On soil, in clusters or in colonies on moss or pine needles in sandy forest of conifers or in mixed woods.

Habitat: in groups among leaf-litter, under conifers. Saprophyte.

Season: June to September.

Specimen examined: On soil, in clusters in mixed forest in Murgiya, 233m, Saljhandi, 262m, Simalpani,1225m, (Rupandehi), (2012); Voucher No. 1008167, Aryal, H.P. New to area of collection. Previously recorded: On Phoksundo Tal [32, 33].

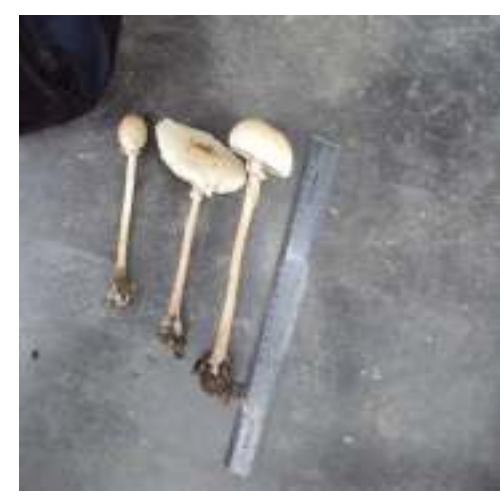

Fig. 3: Macrolepiota procera (Scop.) Sing [34].

Common name: Parasol mushroom.

Local name: Gobbre chyau (Nepali.)

Taxonomic position: Basidiomycetes, Agaricales, Agaricaceae.

\section{Description:}

Usually $12-25 \mathrm{~cm}$ or more high, fruiting body pale colored. Pileus: $7-15 \mathrm{~cm}$ in diameter, at first ovate, then campanulate, finally becoming expanded with an umbo, grayish brown or reddish brown, surface cracking into large, brown scales which are concentrically arranged except at the umbo and small white scales scattered in between the large ones, adpressed scaly or with reflexed roughening, fibrillose edge. Gills: free, crowded but not forked ventricose, white when young and pinkish at maturity, broad in the middle and narrow near the stipe. Stipe: slender, cylindrical, broad, with markedly brown- striped surface with a prominent bulbous base, $15-25 \times 1.5-2 \mathrm{~cm}$, broad, colour paler than the pileus, covered with minute darker scales, hollow, annulus large, band like, conspicuous thick tough, white, movable up and down Flesh: white, soft, in cap and fibrous in stipe, thick. 
Hymenophoral trama: regular Basidia: 4-spored, clavate. Basidiospores: white, ovate to elliptical, apiculate, smooth, with germ-pore, dextrinoid, 13-16 X 8-10 $\mu \mathrm{m}$, metachromatic. Spore print: white. Spore: $15-20 \times$ X 10-13 $\mu \mathrm{m}$. elliptical, smooth, dextrinoid. Pleurocystidia: absent. Hyphae: thin walled. Clamp connections: present. Odor: Pleasant.

Edibility: Edible, delicious.

Distribution: Europe, Japan, China, N. America, India and Nepal.

Habit: Sporophores growing solitary or scattered, sometimes in clusters.

Habitat: on soil, in pastures, lawns, in woods, gardens. Saprophyte.

Season: June to October

Specimen examined: On soil, in Sal forest in Karhiya, 223m, Paklihawa, 90m, Chiliya, 110m, Murgiya,233m, Saljhandi,262m, Simalpani,1225m, (Rupandehi), (2011); Voucher No. 1008118, Aryal, H.P.; new to area of collection.

Previously recorded: Previously recorded from Manichur [35], Phulchowki [36], Nagarjoon [37], Growing under Pine forest, Nagarkot, [38].

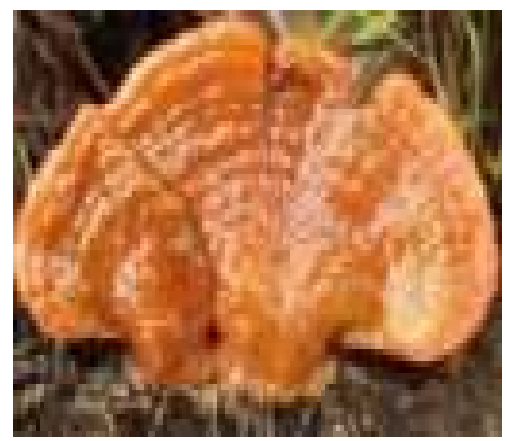

Fig. 4: Pycnoporus cinnabarinus (Jacq.: Fr.) Karst. [23, 39]

Local name: Rato Kathe chyau, Raktey chyau, Sindure chyau.

Taxonomic position: Basidiomycetes, Polyporales, Polyporaceae.

Description:

Fruiting body: Semicircular to kidney-shaped; Plano convex. Carpophore: 3.9 x 1.5-5-7 x 0.5-2.2 $\mathrm{cm}$, bracket-shaped, sessile to sub stipulate, deep orange red, tending to darken dimidiate, at first slightly pubescent then glabrous, fairly rugose, hard on dry in annual, with faint zonation towards margin, thinning from base to periphery, upper surface reddish to almost blackish red at maturity, finely hairy, under surface bright reddish orange with 2-4 round to angular pore; Stipe: absent, Hymeneal surface: waxy, deep red. Tube: 1 - 3mm long, orange-red; Pores: irregular, small, round, pubescent, vermilion 2-4 per mm. Flesh: red, leathery, first spongy then suberose. Spore print: White Spores: white, 5 - 6 X $2-2.5 \mu \mathrm{m}$, hyaline, oblong or short cylindric, smooth, and apiculate, Inamyloid, Hyphal system: trimitic. Cystidia: absent. Odor and Taste: not distinctive.

Edibility: Inedible, (medicinally used for relief from ear pain and to cure cuts and burns).

Distribution: Worldwide. In tropical to temperate belts.

Habit: Clusters on the dead wood, annual.

Habitat: On dead broadleaf branches and trunks. Saprophyte.

Season: June to October.

Specimen examined: On log on Syzygium cumini, Karhiya, 223m, Paklihawa, 90m, Chiliya, 110m, Murgiya, 233m, Saljhandi, 262m, Simalpani,1225m (Rupandehi), (2012); Voucher No. 100711, Aryal, H.P., New to area of collection.

Previously recorded: On dead wood of Alnus nepalensis. Sundarijal, 1500m, [30], Chitwan 200m. [30], Ranipauwa 1600m. [30], Langtang 2200m. [30]. on dead wood, Place not mentioned [40]; Khand Bari [37]; on Betula sp., Chheti gaon, Darchula Dist. [41], Darchula Dist. [42] and Pokhara 
(900m) [43, 44]. And Lamjung [45]. On bark of stump of Alnus nepalensis. Jhakrey, Lumle, 1645m, $[46,47]$.

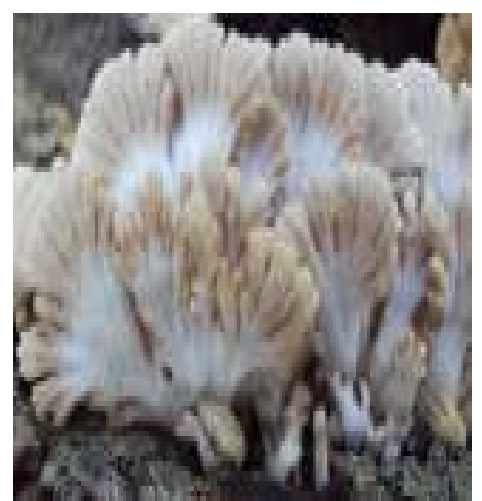

Fig. 5: Schizophyllum commune (Fr.:Fr.) Grev. [27, 48], (Fig. 5)

Local name: Mizu chyau, Kathe Bagale chyau, Kanchat Chyau, Pankhe Chyau.

Taxonomic position: Basidiomycetes, Agaricales, Schizophyllaceae.

\section{Description:}

Tiny fruiting bodies lack stems and they attached themselves like tiny bracket fungi on the dead wood of deciduous trees. Sporophores growing in groups on branches or trunks of trees, on old wood, sometimes on the branches of Shorea robusta, usually coriaceous, tough, pliant when fresh, attached laterally to the substratum Carpophore: Gregarious, 1-5 cm wide, fan or kidney shaped, dry, gray, hairy, whitish gray when dry to brownish gray when moist, margin lobed and hairy; sessile, dry, inclined downward or horizontal, sometimes zoned concentrically Gills: grayish white or pink-tinged, split lengthwise into two layers which tend to curve away from each other, converging radially toward base, where they are attached, edge split and revolute. Stipe: absent, Flesh: tough leathery, gray, becoming whitish and sometimes malodorous as it dries. Hymenophoral trama: not bilateral, hyphae: thick walled Basidia: 4-spored. Basidiospores: hyaline. Oblong with obtuse ends, smooth, non-amyloid, 5-7 x 2-3 $\mu$ m Spore print: white. Cystidia: absent. Spore: 3-4 x 1- 1.5 $\mu \mathrm{m}$. White, straight or curved, smooth. Inamyloid Clamp connection: present.

Edibility: Edible. It is used to eat mixing with other things e.g. cereals. Mostly used by the Newar cast during their marriage ceremony as Sagun (better happening). Used in soups, by Magar, Newar and Tharu (Bara district) ethnic casts. This fungus causes a disease known as basidioneuromycois in human being [25]. Better to avoid.

Distribution: Worldwide. In tropical to temperate belts.

Habit: in clusters on log.

Habitat: On wood, stumps, dead trunks or living trees in poor health. Besides growing on wood, it has also been found on animal matter (saprophytic on whalebone or, in mycelia form with no fruitbody, on scar tissue in a human mouth).

Ecology: Saprobic on dead wood or sometimes parasitic on living wood.

Season: July to September.

Specimen examined - On decay wood (Shorea robusta), in sal forest, Karhiya, 223m, Paklihawa, 90m, Chiliya, 110m, Murgiya, 233m, Saljhandi, 262m, Simalpani,1225m, (Rupandehi); (2012); Voucher No. 101002, Aryal, H.P., New to area of collection.

Previously recorded: on dead wood, place not mentioned [40]; growing on decayed wood, Ranipauwa, Kaligandaki [33], Bagarchhap [49], Pokhara [43, 42]. Khand Bari [37]; on Betula sp., Chheti gaon, Darchula Dist. [41] and on the logs, stumps and sticks of Alnus nepalensis, Jhakrey, Lumle, 1645m, [47]. In tropical to temperate belts [43]. On the logs, stumps and sticks of Alnus 
nepalensis, Sundarijal, 1440m, Sundhara (Kath) Swayambhu, Champadevi, Bishalnagar (Kath), Namobudha (Kavre), Nagarkot [30].

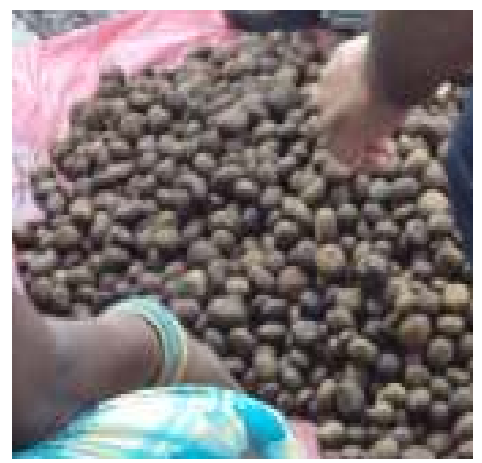

Fig. 6: Scleroderma texense Berk. [48, 50, 51], (Fig.6)

Local name: Kudaki Chyau, Kutaki Chyau, Paduke Chyau. Bhundki, Dalle, Phutuki.

Taxonomic position: Basidiomycetes, Boletales, Sclerodermataceae.

Description:

Basidiocarp: 1-2 cm, whitish, subterranean or superficial globose, sessile sometimes prolonged into a stem like base. Peridium: simple, rarely double smooth or rough with pale brown warts on the upper part outer layer composed of hyaline, loosely and irregularly arranged hyphae of $2-2.5 \mu \mathrm{m}$ diameter, inner layer whitish, composed of hyaline, anastomosing hyphae of $5 \mu \mathrm{m}$ diameter and irregular shaped hyaline cells of 7-7.5 $\mu \mathrm{m}$ diameter. Gleba: traversed by sterile veins, pale white when young, becoming sooty black with age. Dehiscence: irregular. Capillitium: rudimentary, consisting of only remnants of sterile hyphae. Spores: $6.25-10 \mu \mathrm{m}$ diameters, globose, purplish brown to black, wall darker, echinulate.

Edibility: Edible. Rs. 350 to $450 /$ per $\mathrm{Kg}$, in the local market. Very common. Eaten raw as well as roasted in fire or cooked as vegetable.

Distribution: Europe, India Thailand, Nepal.

Habit: Growing buried or on soil in Shorea robusta forest. Mainly in tropical Dipterocarp forest. Nepal (East to West: tropical belt of Shorea robusta forest).

Habitat: Ectomycorrhizal fungi.

Specimen examined: On soil, in Sal forest, Karhiya, 223m, Paklihawa, 90m, Chiliya, 110m, Murgiya, 233m, Saljhandi, 262m, Simalpani,1225m, (Rupandehi), (2011); Voucher No. 1009152, Aryal, H.P., New to area of collection.

Previously recorded on Chuche Khola, Hetauda, Makawanpur District, growing buried or on soil, [51].

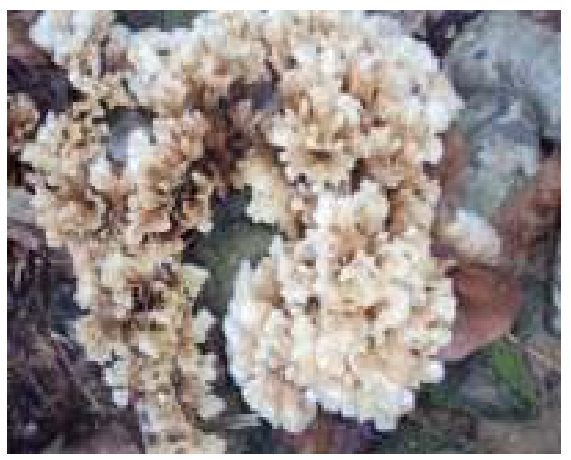

Fig.7: Sparassis crispa (Wulfen) Fr. [6, 7, 9, 20, 23]. 
Common name: Cauliflower fungus, wood cabbage, Coat of wood, Brain fungus.

Local name: Cauli chyau, Thakre chyau, Fursey chyau, Chyapkey, Fyaleshymo (Tamang).

Taxonomic position: Basidiomycetes, Agaricales, Pluteaceae.

\section{Description:}

Sporophores growing usually at base of conifer, $15-40 \mathrm{~cm}$ high, Carpophore 10-60 cm, Fleshy, erect, densely branched from a short stout rooting stipe. Flattened and curled lobes resembling a cauliflower head from a distance, whitish or ochraceous when young, black with maturity, white to pale yellow in colour. Stipe: very short, stout, whitish at first, turning black when old. Flesh: firm, tough, elastic, whitish or faintly pale yellow, fragile, brittle. Odor: pleasant. Hymenium: smooth. Basidia: 4-spored Basidiospores: white, buff in mass, pip-shaped. Spore print: whitish. Spores: whitish to light ochre, ovoid, smooth, 6-7 x 3-5 $\mu$ m. inamyloid. Clamp connection: present

Edibility: edible. Young fruit bodies are very good in taste.

Distribution: North America, Europe, China, Japan, India and Nepal.

Habit: on colonies in dead wood.

Habitat: On coniferous wood, at the foot of trees or on roots. it grows on the ground near trees or on very rotten wood in broadleaf woodlands. Parasitic

Season: July-October.

Specimens examined: On log (Tectona grandis), Karhiya, 223m, Paklihawa, 90m, Chiliya, 110m, Murgiya, 233m, Saljhandi, 262m, Simalpani,1225m, (Rupandehi); (2011); Voucher No. 100748; New to area of collection.

Previously recorded:

At the base of Quercus lamellose,Pahiro,1660m, at the base of Quercus semecarpifolia, Dhunche, 1960m, Lama hotel, 2840m, Chandanbari, 3250, at the base of Tsuga demosa, Thulo syafru, 2120m, Ghoda Tabela, 3000m, Cholangpati, 3585m [52].

\section{Conclusion}

The gathering of mushrooms shows that there are plenty of species, which are said to be edible and of medicinal value. Many mushroom species are gathered by local people for their daily livelihood and trade. They are sacked in bags and carried to market even for sell. The tropical species like Amanita chepangiana seem to be widespread in the terai and siwaliks belt of Nepal. The medicinally important tropical polypore like Pycnoporus cinnabarinus has been gathered for the remedy of infectious disease (Mump), Ear pain etc. The cosmopolitan species like Schizophyllum commune the inedible fungi is sometimes used for culinary proposes in food deficit condition. This species has religious value also and is used as 'Sagun' for better happening in the marriage ceremony in Newar community. The Dipterocarp inhibiting mycoelements like Scleroderma texense has been used both for food and medicine.

During surveys, it was found that the population of Amanita chepangiana, Macrolepiota fuliginosa Scleroderma bovista, and Sparasis crispa are declining since the last two decades due to deterioration of forest. So, it is visualized from the field survey that some of the important species need special attention to conserve against the threat to avoid their unmanaged and unscientific exploitation by the people. It is therefore necessary to conserve natural habitat of mushroom diversity for the sustainable development. The government should take special attention on these aspects.

\section{Acknowledgements}

The authors would like to acknowledge Nepal Academy of Science and Technology for providing the Ph.D. research grant; thanks are due to the Central Department of Botany, Tribhuvan University for providing laboratories facilities. We are also grateful to the Institute of Science and Technology for granting study leave to one of them (Mr. H.P. Aryal). Sincere thanks are extended to local informants of the study area for providing information. 


\section{References}

1. H.H. Burdsall and O.K. Miller, Type studies and nomenclatural considerations in the genus Sparassis. Mycotaxon, 31(1988)199-206.

2. M Christensen, S. Bhattarai, S. Devkota and H. O Larsen, Collection and use of wild edible fungi in Nepal. Eco. Bot. 62 (1) (2008) 12-23.

3. D.F.O. (District Forest Office). Rupandehi: Brief Introduction and Progress Report, 2012.

4. GoN. (Government of Nepal). Climatological and agro meteorological records of Nepal. Ministry of Environment, Science and Technology. Department of Hydrology and Meteorology, Kathmandu, Nepal., 2010.

5. D.L. Hawksworth, P.M. Kirt, B.C. Sutton and D.N. Pegler. Ainsworth and Bisby's Dictionary of Fungi, International Mycological institute CAB International, Eighth Ed. (1995), Pp. 616.

6. E.M. Fries, Systema Mycologicum. E. Marituis Uppsala,1821.

7. E.M. Fries, Elenchus Fungorum Srstens Commenterium in system mycologicum, 1:1 (1828) 1-238:227.

8. E.M. Fries, Epicrisis Systematics mycologici. Upasala. 1938.

9. P.A. Saccaedo, Sylloge Fungorum VI (1888) 690.

10. W.A. Murril, Kashmir Fungi. Mycologia 16 (1924) 133.

11. E.J.H. Corner, Supplement to a monograph of Clavaria and allied genera, Nova Hedwigia. 33 Verlag von. J. Cramer, 1970.

12. B.K. Bakshi, Indian Polyporaceae. Indian Council of Agriculture Resources, New Delhi., 1971.

13. M. Mckenenny, The savory wild mushroom. University of Washington press, USA, 1971.

14. M. Svreck, A colour guide to familiar Mushrooms. Octopus Book Company, 1975.

15. C. Dickinson and J. Lucas, Encyclopedia of Mushrooms. Orchid Publication, London, 1979.

16. G. Kibby, Mushrooms and Toadstools. Oxford University Press, London, 979.

17. J. Webster, Introduction to Fungi. Cambridge University Press, Cambridge, Second Ed., 1980.

18. R. Phillips, Mushrooms and other Fungi of Great Britain and Europe. Pan Book Ltd. London. Pp.252-53. (1981).

19. G. Pacioni, The Mcdonald's encyclopedia of mushrooms and toadstools. Mcdonald \& Co. Ltd. London, 1985.

20. R. P. Purukayastha, and A. Chandra, Manual of Indian edible mushrooms. Jagendra Book Agency. India, New Delhi, 1985.

21. D. Arora, Mushroom demystified a comprehensive guide to the fleshy fungi, Brekley Ten speed Press, 1986.

22. R. Singer, The Agaricales in modern taxonomy, Bishen Singh Mahendra Pal Singh, Dehradun, India, Fourth Ed., 1986.

23. R. Imazeki, Y. Otani and T. Hongo, Colored Illustration of Fungi of Japan, YAMAKEI Publishers Co. Ltd., Japan, Tokyo, 1988.

24. A. Kummar, R.P. Bhatt and T.N. Lakhanpal, The Amanitaceae of India, Bishen Sing Mahendra Pal Singh, 23- A, , India, Deharadun, 1990.

25. M.H. Zoberi, Tropical macro fungi Mac million, London, 1972.

26. R.E. Tulloss and H.R. Bhandary, Amanita Chepangiana; a new species from Nepal. Mycotaxon. XLLIII (1992): 25- 31.

27. M. K. Adhikari, Mushroom of Nepal. P.U. Printer, Kathmandu, Nepal.(2000), pp.236.

28. M.K. Adhikari and G. Durrieu, Ethnomycologie Nepalaise. Bull. Soc. Myc. France. 112 (1996): 31-41.

29. M.K. Adhikari, S. Devkota and R.D. Tiwari, Ethno mycological knowledge on uses of wild mushrooms in western and central Nepal. Our nature. (A Biological journal). 3(1) (2005) 13-19.

30. N. Pandey, Mushroom Diversity in central Nepal: An ethnomycological Approach. Ph.D. Thesis, Central Department of Botany, Tribhuvan University, Nepal. (2008), pp.255.

31. E.J. Butler and G.R. Bisby, The fungi of India, (1960), pp. 208. 
32. H. Kreisel, Gasteromyzeten aus Nepal. II. Feddes Reportorium. 87(1976) 83-107.

33. F.L. Balfour-Browne, Fungi of recent Nepal expedition. Bull. Brit. Mus. (Nat. Hist.) Ser. Bot. 4(1968) 99-141.

34. R. Singh and U. C. Singh, Modern Mushroom Cultivation, Agro bios (India) (2005), pp. 33.

35. M.K. Adhikari, Chyau: ek charcha (=Mushrooms: a discussion). Gorkhapatra. (Kath.) 76(1976). (2033.8.10 B.S.) 6. (in Nepali).

36. S.C. Singh and N. Singh. Some fleshy fungi of Nepal. Jour. Sci. 6(1976) 83-88.

37. B. D. Pandey, Survey, collection, presentation and identification of the mushrooms in Nepal. Nep. Jour. Agri. 6-11(1976) 115-129.

38. M.K. Adhikari, and V. Manandhar, New record of Calvatia gigantea from Kathmandu Valley, Nepal. Nat. Hist. Soc. Nep. Bull 8 (1-4) (1998) 10.

39. P.A. Karsten,. Enumeratio Boletinearum et Polyporearum. Revue. Mycol., Toulouse 3 (no.9), (1881), pp.18.

40. M.J. Berkeley, Decades of fungi, Decades XLIX-L. Indian fungi. Hooker's Jour. Bot., Kew. Gard. Misc. Jour. 6(1854) 225-247(reprint 1969, Decades of fungi 1-62, Amsterdam, Asher Co. pp. 280).

41. M.K. Adhikari, Polyporales (wood rotting fungi) of Nepal. Ban ko Janakari. 2(1) (1988) 9-20.

42. M.K. Adhikari, and V. Manandhar, Fungi of Nepal, Part 1: Historical review \& Myxomycotina. Bull. Dept. Med. Pl. 13(1996) 1-69.

43. M.K. Adhikari, Biodiversite des Basidiomycetes au Nepal: etude systematique et Biogeographique. Specialite Ecologie-Mycologique. These du Doctorat de L'Universite present devant 1'Universite Paul Sabatier, Toulouse, France. no. d'ordre 2309, (1996), pp. 205.

44. M.K. Adhikari and P. Parajuli, Mycorrhizal fungal diversity in the pine forests of Kathmandu valley, Nepal. In abstracts of the paper, ECOS (1996), pp. 182-187.

45 S. Adhikari and M.K. Adhikari, Some higher fungi from Lamjung Nepal. Botanica Orientalis. 3(2003) 133-134.

46. S. Devkota, Mushroom Diversity In Lumle (Kaski) and Study of Clavariales from Lumle and Vicinity of Kathmandu Valley, Nepal. M. Sc. Thesis, Central Department of Botany, Tribhuvan University, Nepal, 2005.

47. S. Devkota, R.D. Tiwari, V.K. Manandhar and M.K. Adhikari, Some wild mushrooms collected from Lumle, Kaski, Nepal. Bull. Dept. Pl. Res. 26(2005) 10-15.

48. S.C. Teng, Higher fungi of China. (1988), pp. 444, 448 \& 504.

49. H.R. Bhandary, Some edible and medicinal fungi from Dumre to Manag, Mustang and Pokhara. Jour. Nat. Hist. Mus. 12(1-4) (1991) 47-60.

50. K.P. Sims, R. Watling and P. Jeffries, A revised key to the genus Scleroderma, Mycotaxon, Vol. LVI (1995) 403-420.

51. V. Manandhar and M. K. Adhikari. The family Sclerodermataceae: ectomycorhizal fungi from Nepal. Bull. Dept.Pl.Res. 31(2009) 29-34.

52. S. Devkota, Distribution and Status of Highland Mushroom: A Study from Dolpa, Nepal. J. Nat. Hist. Mus. 23(2008) 51-59.

53. Websites: www.biodiversitylibrary.org, www.Indexfungorum.org, www.Jstor.org, www.Mycobank.org, www.scihub.org, www.scirus.com, www.tropicos.org 